\title{
Diurnal variations of progesterone, testosterone, and androsta-1,4- diene-3,17-dione in the rumen and in vitro progesterone transformation by mixed rumen microorganisms of lactating dairy cows
}

\author{
Qing-Chang Ren, ${ }^{*}$ Hong-Jian Yang, ${ }^{* 1}$ Sheng-Li Li, ${ }^{*}$ and Jia-Qi Wang† \\ *State Key Laboratory of Animal Nutrition, College of Animal Science and Technology, China Agricultural University, Beijing 100193, PR China \\ †State Key Laboratory of Animal Nutrition, Institute of Animal Science, Chinese Academy of Agricultural Sciences, Beijing 100193, PR China
}

\begin{abstract}
Five Holstein lactating dairy cows fed 5 total mixed rations (TMR) with different forage combinations were used in a $5 \times 5$ Latin square design to investigate diurnal variations of progesterone (P4), testosterone, and androsta-1,4-diene-3,17-dione (ADD) concentrations in the rumen. Meanwhile, different $\mathrm{P} 4$ inclusion levels $[0$ (control), 2, 20, 40, 80, and $100 \mathrm{ng} / \mathrm{mL}$ in culture fluids] were incubated in vitro for $6,12,24,36,48$, and $72 \mathrm{~h}$ together with rumen mixed microorganisms grown on a maize-rich feed mixture (maize meal:Chinese ryegrass hay $=4: 1$ ) with an aim to determine microbial $\mathrm{P} 4$ transformation into testosterone and ADD. Ruminal $\mathrm{P} 4$, testosterone, and ADD concentrations of lactating dairy cows were greater in the TMR with forage combination of corn silage plus alfalfa hay or Chinese wild ryegrass hay than the TMR with the corn stover-based forage combination. The diurnal fluctuation pattern showed that $\mathrm{P} 4$, testosterone, and ADD concentrations in the rumen were greater at nighttime than daytime and peaked $6 \mathrm{~h}$ after feeding in the morning or afternoon. The in vitro batch cultures showed that the P4 elimination rate was highest at the $\mathrm{P} 4$ addition of 20 $\mathrm{ng} / \mathrm{mL}$ and declined with the further increased addition of $\mathrm{P} 4$. The treatments after dosing $\mathrm{P} 4$ exhibited a shorter time than the control group until half of the initial P4 inclusion was eliminated (i.e., half time), and the lowest half time $(1.46 \mathrm{~h})$ occurred at the $\mathrm{P} 4$ addition of $20 \mathrm{ng} / \mathrm{mL}$. In summary, the ruminal steroids concentration was affected by forage type and quality, and the rumen microorganisms exhibited great ability to transform P4 into testosterone and ADD, depending on incubation time and initial P4 addition level, suggesting that the host might affect the metabolism of its rumen microorganisms via the endogenous steroids. Key words: dairy cow, rumen, progesterone
\end{abstract}

Received October 14, 2013.

Accepted January 25, 2014.

${ }^{1}$ Corresponding author: yang_hongjian@sina.com

\section{INTRODUCTION}

Progesterone (P4), consisting of ketones, oxidation functionality, and 2 methyl subunits, is an ovarian steroid hormone produced by the corpus luteum, placenta, and adrenalin gland (Rothchild, 1981), and plays an important role in the development, differentiation, metabolism, and reproduction in the female (Mani, 2003). Previous P4 research in sheep suggests that the corpus luteum attained full secretory activity between d 6 and 8 of the estrous cycle and continued to secrete $\mathrm{P} 4$ at a constant rate until $\mathrm{d} 15$; thereafter the P4 secretion declined until the next estrous cycle (Cunningham et al., 1975). Similarly, Stabenfeldt et al. (1969) noted that the serum P4 concentration in dairy cattle increased rapidly from d 3 to 8 during the estrous cycle, continuously increased at a much lower rate from d 8 to 17 , and then sharply declined toward the end of the cycle. At peak luteal function, $\mathrm{P} 4$ levels varied from $0.4 \mathrm{ng} / \mathrm{mL}$ of plasma at estrus to approximately $7 \mathrm{ng} / \mathrm{mL}$ of plasma, with a range of 6.1 to $10.2 \mathrm{ng} / \mathrm{mL}$ (Stabenfeldt et al., 1969).

Previous studies reported that P4 in sheep entered the reticulorumen through the wall of forestomach and saliva cycle (Borisenkov et al., 2003; Borisenkov et al., 2006). The level of P4 circulating concentration was determined by a balance between $\mathrm{P} 4$ production primarily by the corpus luteum and $\mathrm{P} 4$ metabolized primarily by the liver in a monogastric animal (Wiltbank et al., 2012). To date, there are 2 well-known pathways for the cleavage of the side chain of P4 (Figure 1). The first pathway (Figure 1a) is demonstrated in the liver and tissues of human and monogastric animals (Richards and Hendrickson, 1964), and another pathway of microbial side chain transformation (Figure 1b) was observed in Cladosporium resinae (Fonken et al., 1960). The microbial side chain transformation of $\mathrm{P} 4$ in the latter pathway, which resulted in testosterone, androsta-1,4-diene-3,17-dione (ADD), and testololactone or their 1-dehydroderivatives, was further confirmed in Streptomyces griseus (Carlström, 1966) and Streptomyces denitrificans (Leu et al., 2011). 


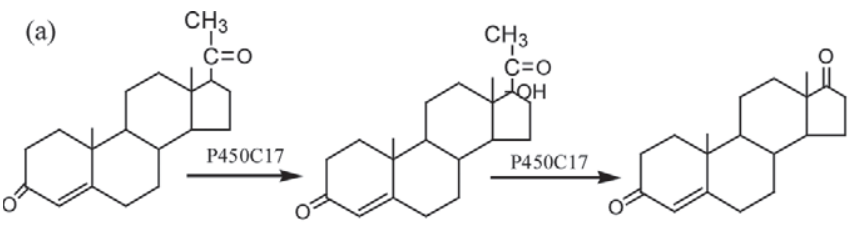

Progesterone 17alpha-hydroxyprogesterone Androst-4-en-3,17-dione
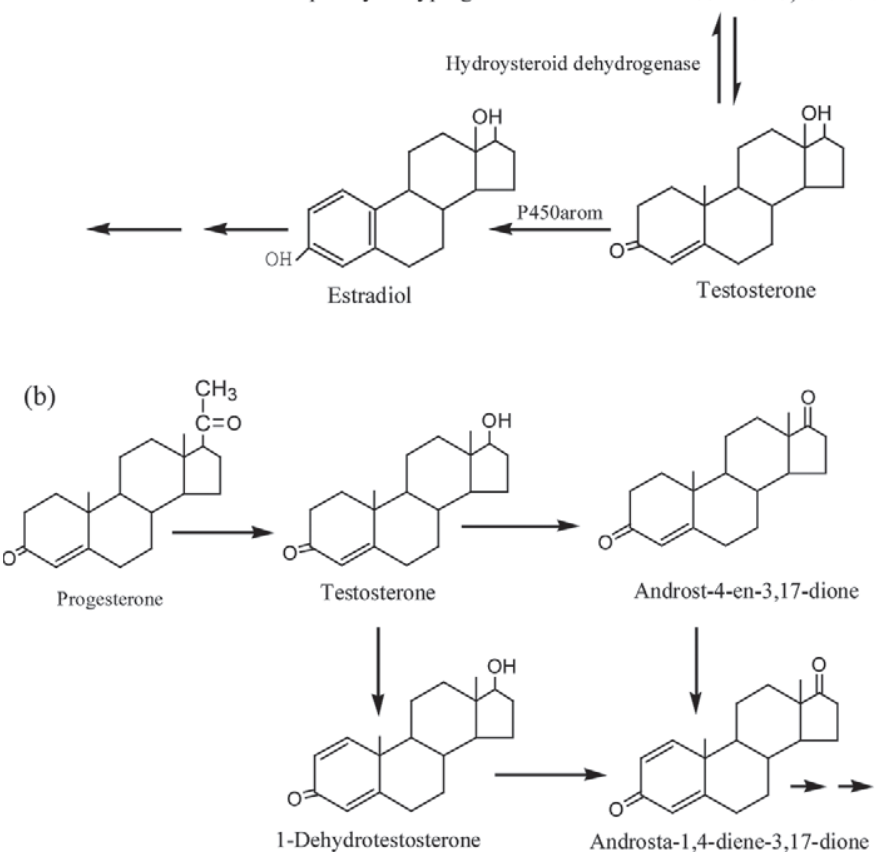

Figure 1. Transformation pathway of progesterone in the adrenal cortex and the gonadal cells of human and animals (a; Hanukoglu, 1992) and in microorganisms (b) of Streptomyces griseus (Carlström, 1966) and Streptomyces denitrificans DSMZ18526 (Leu et al., 2011).

Until now, previous studies mainly focused on P4 level in serum and $\mathrm{P} 4$ transformation by environmental microorganisms, but information associated with ruminal P4, testosterone, and ADD concentrations and the fate of P4 entering the rumen has not been well investigated in ruminant animals. In the present study, we investigated the diurnal variation of $\mathrm{P} 4$, testosterone, and ADD concentrations in rumen fluids of lactating dairy cow fed 5 high-concentrate TMR with different forage combinations. Meanwhile, microbial P4 transformation into testosterone and ADD was determined in mixed rumen microorganisms grown on a maize-rich feed mixture with in vitro batch cultures at different incubation times.

\section{MATERIALS AND METHODS}

All experiments in the present study were conducted at the China Agricultural University, State Key Laboratory of Animal Nutrition (Beijing, China). The dairy cows used were cared for in accordance with the practices outlined in the Guide for the Care and Use of Agri- cultural Animals in Agricultural Research and Teaching of the China Agricultural University Animal Care and Use Committee.

\section{In Vivo and In Vitro Experiments}

Experiment 1. Five lactating, nonpregnant Holstein cows of 2 breeds (BW $=543 \pm 25 \mathrm{~kg}$; daily milk yield $=20 \pm 2 \mathrm{~kg}$; DIM $=60 \pm 13 \mathrm{~d}$; parity $=2$ ) were fitted with rumen cannulas (Type 2C; Bar Diamond Inc., Parma, ID) and served as experimental animals. The animals were confined in individual $10-\mathrm{m}^{2}$ concrete-floor pens, each of which had a separate feed bunk and watering point, and water was available for ad libitum consumption. The surgical preparation of cows was done 6 mo before the start of the present study to ensure health recovery. A $5 \times 5$ Latin square experiment design was applied to investigate effects of 5 TMR with different forage combinations on diurnal variations of $\mathrm{P} 4$, testosterone, and $\mathrm{ADD}$ concentrations in the rumen of the lactating dairy cattle. Five TMR (Table 1) were formulated at same ratio of concentrate to forage (61:39), and forage combinations in the TMR were designed as follows: TMR $1=390 \mathrm{~g} / \mathrm{kg}$ of corn stover, TMR2 $=195 \mathrm{~g} / \mathrm{kg}$ of corn stover plus $195 \mathrm{~g} / \mathrm{kg}$ of ensiled corn stover, TMR3 $=195 \mathrm{~g} / \mathrm{kg}$ of ensiled corn stover plus $195 \mathrm{~g} / \mathrm{kg}$ of Chinese wild ryegrass (Leymus chinensis) hay, TMR $4=195 \mathrm{~g} / \mathrm{kg}$ of Chinese wild ryegrass hay plus $195 \mathrm{~g} / \mathrm{kg}$ of whole corn silage, and TMR5 $=132.6 \mathrm{~g} / \mathrm{kg}$ of Chinese wild ryegrass hay plus 128.7 $\mathrm{g} / \mathrm{kg}$ of whole corn silage plus $128.7 \mathrm{~g} / \mathrm{kg}$ of alfalfa hay. The cows were fed the TMR twice daily at 0700 and $1900 \mathrm{~h}$. The nutrient levels are shown in Table 1. The whole experiment was completed in 5 periods and each period was carried out for $18 \mathrm{~d}$; the cows were gradually adapted to the corresponding TMR from d 1 to 15 , and the rumen fluids were intensively collected on $\mathrm{d}$ 16,17 , and 18 of each period. The rumen contents of the lactating dairy cattle were collected at 0100, 0700, 1300, and $1900 \mathrm{~h} \mathrm{(d} \mathrm{16);0300,0900,} \mathrm{1500,} \mathrm{and} 2100 \mathrm{~h}$ (d 17); and 0500, 1100, 1700, and $2300 \mathrm{~h}$ (d 18). The samples were collected from different compartments of the rumen via rumen cannulas using a vacuum pump, pooled in equal portions, mixed thoroughly by hand, and filtered through 4 layers of muslin. The mixed samples were then centrifuged at 1,000 $\times g$ for $30 \mathrm{~min}$ at $4^{\circ} \mathrm{C}$. The supernatant of the rumen liquid fraction was immediately stored at $-20^{\circ} \mathrm{C}$ for later chemical analyses of $\mathrm{P} 4$, testosterone, and ADD concentrations.

Experiment 2. Chinese wild ryegrass at late-bloom stage used in experiment 1 was chopped with a paper cutter and oven-dried at $65^{\circ} \mathrm{C}$ for $36 \mathrm{~h}$. Oven-dried ryegrass hay and maize meal were ground in a Wiley mill (Arthur H. Thomas Co., Philadelphia, PA) to pass 
Table 1. Feed ingredient and nutritive level of 5 TMR differing in forage combination

\begin{tabular}{|c|c|c|c|c|c|}
\hline Composition & TMR1 & TMR2 & TMR3 & TMR4 & TMR5 \\
\hline \multicolumn{6}{|l|}{ Feed ingredient (g/kg) } \\
\hline Corn stover & 390.0 & 195.0 & & & \\
\hline Ensiled corn stover & & 195.0 & 195.0 & & \\
\hline Chinese wild ryegrass & & & 195.0 & 195.0 & 132.6 \\
\hline Whole corn silage & & & & 195.0 & 128.7 \\
\hline Alfalfa hay & & & & & 128.7 \\
\hline Concentrate $^{1}$ & 610.0 & 610.0 & 610.0 & 610.0 & 610.0 \\
\hline \multicolumn{6}{|l|}{ Nutritive level on a DM basis } \\
\hline $\mathrm{NE}_{\mathrm{L}}^{2}(\mathrm{MJ} / \mathrm{kg}$ of $\mathrm{DM})$ & 6.1 & 6.2 & 6.3 & 6.4 & 6.5 \\
\hline $\mathrm{CP}(\mathrm{g} / \mathrm{kg}$ of $\mathrm{DM})$ & 146.8 & 148.6 & 150.2 & 151.5 & 159.0 \\
\hline Ether extract $(\mathrm{g} / \mathrm{kg}$ of $\mathrm{DM})$ & 12.6 & 13.9 & 14.5 & 14.6 & 14.7 \\
\hline $\mathrm{NDF}(\mathrm{g} / \mathrm{kg}$ of DM) & 297.8 & 312.8 & 334.0 & 311.4 & 289.5 \\
\hline $\mathrm{ADF}(\mathrm{g} / \mathrm{kg}$ of $\mathrm{DM})$ & 181.6 & 192.9 & 198.9 & 180.6 & 190.3 \\
\hline $\mathrm{NFC}^{3}(\mathrm{~g} / \mathrm{kg}$ of $\mathrm{DM})$ & 451.7 & 428.9 & 412.2 & 441.7 & 445.9 \\
\hline Calcium (g/kg of DM) & 5.3 & 5.6 & 5.6 & 5.7 & 8.1 \\
\hline Phosphorus (g/kg of DM) & 4.2 & 4.3 & 4.6 & 5.0 & 5.0 \\
\hline
\end{tabular}

${ }^{1}$ The concentrate (per kilogram of DM) contained $538.8 \mathrm{~g}$ of maize meal, $142.3 \mathrm{~g}$ of soybean meal, $71.1 \mathrm{~g}$ of cottonseed meal, $40.7 \mathrm{~g}$ of rapeseed meal, $50.8 \mathrm{~g}$ of wheat bran, $122.0 \mathrm{~g}$ of distillers dried grains, $10.2 \mathrm{~g}$ of salt, $10.2 \mathrm{~g}$ of calcium hydrogen phosphate, $10.2 \mathrm{~g}$ of limestone, and $3.2 \mathrm{~g}$ of premix per kilogram. The premix contained 2,100 $\mathrm{mg}$ of I, 2,000 $\mathrm{mg}$ of $\mathrm{Cu}, 2,500 \mathrm{mg}$ of Mn, 8,000 mg of Zn, $60 \mathrm{mg}$ of Se, $20 \mathrm{mg}$ of Co, $950 \mathrm{kIU}$ of vitamin A, $400 \mathrm{kIU}$ of vitamin D, and $7.5 \mathrm{kIU}$ of vitamin $\mathrm{E}$ per kilogram.

${ }^{2}$ The $\mathrm{NE}_{\mathrm{L}}$ was calculated according to NRC (2001).

${ }^{3}$ The NFC was calculated as follows: NFC $=100-(\mathrm{NDF}+\mathrm{CP}+$ ether extract + ash $)$.

through a 2 -mm screen, and then mixed at a ratio of 1 to 4 portions, resulting in a maize-rich substrate for later in vitro batch culture. Progesterone was purchased from Sigma Chemical Co. (St. Louis, MO), and its stock solutions were prepared by dissolving methanol and $10 \mathrm{mg}$ of $\mathrm{P} 4$ in $100 \mathrm{~mL}$ of pure methanol (Fisher Scientific Chemical, Fair Lawn, NJ). Thereafter, 0.075, $0.75,1.5,3.0$, and $3.75 \mathrm{~mL}$ of the stock solutions were respectively added to $50 \mathrm{~mL}$ of pure methanol, resulting in final P4 concentrations of 150, 1,500, 3,000,6,000, and $7,500 \mathrm{ng} / \mathrm{mL}$, respectively, for the use in the later in vitro batch cultures.

A completely randomized design was applied to 5 runs of in vitro batch cultures with $6 \mathrm{P} 4$ dose rates of 0 (control), 2, 20, 40, 80, and $100 \mathrm{ng} / \mathrm{mL}$ in culture fluids. In each run, rumen fluids from 5 cows in each period of experiment 1 were filtered, mixed in equal portions, and served as donors of mixed rumen microorganisms. Five glass bottles (volume capacity of $140 \mathrm{~mL}$ ) per P4 dosage per incubation time with butyl rubber stoppers and screw caps were used as incubators. The maize-rich feed mixture $(500 \mathrm{mg})$ was weighed into the bottles. Afterward, $25 \mathrm{~mL}$ of filtered rumen fluid taken $1 \mathrm{~h}$ before the morning feeding and $50 \mathrm{~mL}$ of freshly prepared buffer solution ( $\mathrm{pH}$ 6.85; Menke and Steingass, 1988) were added to the bottles, and then the $\mathrm{P} 4$ working solutions $(1 \mathrm{~mL})$ were added to achieve final P4 levels of 2, 20, 40, 80, and $100 \mathrm{ng} / \mathrm{mL}$ culture fluid. The bottles in the $\mathrm{P} 4$ control group had $1.0 \mathrm{~mL}$ of pure methanol added to them. Meanwhile, 5 negative-control bottles without P4 and without methanol were arranged. Three bottles without the substrate and $\mathrm{P} 4$ dose were included in each run as blanks and, if necessary, to check variation between the runs caused by differences in the rumen fluid inoculum from different periods. All the bottles were purged with anaerobic $\mathrm{N}_{2}$ for $5 \mathrm{~s}$, sealed with butyl rubber stoppers and screw caps, and then incubated at $39^{\circ} \mathrm{C}$.

To investigate if other elements in the rumen fluids affect the transformation of $\mathrm{P} 4$, the rumen fluids were centrifuged at $25,000 \times g$ at $4^{\circ} \mathrm{C}$ for 20 min to obtain the microbe-free inoculant, and the $\mathrm{P} 4$ dosing solutions $(1 \mathrm{~mL})$ were incubated together with $25 \mathrm{~mL}$ of the microbe-free inoculant and $49 \mathrm{~mL}$ of the freshly prepared buffer solution (pH 6.85; Menke and Steingass, 1988) as described above.

After $6,12,24,36,48$, and $72 \mathrm{~h}$ of incubation, 5 bottles of each treatment were withdrawn at each incubation time. Then, all culture fluids were filtered with nylon bags with a pore size of $48 \mu \mathrm{m}$. Three aliquots of the filtered culture fluids $(5 \mathrm{~mL})$ were sampled for later extraction and chemical analyses of $\mathrm{P} 4$, testosterone, and ADD concentrations.

\section{Extraction of P4, Testosterone, and ADD}

Following the extraction method of Wadhwa and Smith (2000), the filtered rumen fluid ( $5 \mathrm{~mL}$ ) in experiment 1 or the filtered culture fluid $(5 \mathrm{~mL})$ in experiment 2 and $10 \mathrm{~mL}$ of pure methanol used in the experiment were added to $20-\mathrm{mL}$ volume tubes, and the tubes were then shaken at $80 \mathrm{rpm}$ for $2 \mathrm{~min}$ and centrifuged at 
$10,000 \times g$ for $10 \mathrm{~min}$ at $4^{\circ} \mathrm{C}$. The above extraction with pure methanol was repeated 3 times, and the combined supernatants were mixed, shaken again for $2 \mathrm{~min}$, and then evaporated to dryness at $50^{\circ} \mathrm{C}$. Finally, the residue pellets containing $\mathrm{P} 4$, testosterone, and $\mathrm{ADD}$ again were redissolved in $1 \mathrm{~mL}$ of pure methanol and filtered by an organic filter membrane with a pore size of $0.22 \mu \mathrm{m}$ for the later HPLC analysis.

\section{P4, Testosterone, and ADD Analysis}

The standard chemicals P4, testosterone, and ADD were purchased from Sigma Chemical Co., weighed, and dissolved in pure methanol to prepare 3 working solutions containing $1,000 \mathrm{ng}$ of $\mathrm{P} 4 / \mathrm{mL}, 1,000 \mathrm{ng}$ of testosterone $/ \mathrm{mL}$, and $1,000 \mathrm{ng}$ of $\mathrm{ADD} / \mathrm{mL}$, respectively. The working standard solutions were separately diluted with pure methanol to obtain a series of standard solutions with 5 different concentrations of the analyte, and standard curves for P4, testosterone, and ADD were then made according to the known analyte concentrations and detected peak areas following the HPLC method of Wang et al. (2006). The detected concentrations of $\mathrm{P} 4$, testosterone, and ADD represented $91.7( \pm 2), 95.3( \pm 1)$, and $89.5 \%( \pm 3 \%)$ of the analyte redissolved in pure methanol (i.e., P4: 0.52-100.2 ng/ $\mathrm{mL}$; testosterone: $0.5-200.2 \mathrm{ng} / \mathrm{mL}$; ADD: 0.1-100.5 $\mathrm{ng} / \mathrm{mL}$ ). The HPLC separation and UV detection system used included a Wufeng analytical instrument (Shanghai Wufeng Scientific Instruments Co. Ltd., Shanghai, China) consisting of a LC-P100PLUS pump, a LC-UV100PULS UV detector, a LC-CO100PLUS column heater, and a manual sampling injector with a $25-\mu \mathrm{L}$ loop. The analytical column used in the present study was a Symmetry reverse-phase C18 column (250-mm length $\times 4.6-\mathrm{mm}$ i.d., 5 - $\mu \mathrm{m}$ particle size, $\mathrm{pH}$ 2-8; Waters Corp., Milford, MA). Acetonitrile and water were used as mobile phase, and a flow rate of $1 \mathrm{~mL} / \mathrm{min}$ was set for the mobile phase. The variable wavelength detector settings were as follows: 0 to 3.7 min: acetonitrile:water $=65: 35(\mathrm{vol} / \mathrm{vol})$ at $190 \mathrm{~nm}$ for ADD concentration; 3.7 to 5.0 min: acetonitrile:water $=75: 25(\mathrm{vol} / \mathrm{vol})$ at $245 \mathrm{~nm}$ for testosterone; and 5.0 to $8.0 \mathrm{~min}$ : acetonitrile:water $=85: 15(\mathrm{vol} / \mathrm{vol})$ at $241 \mathrm{~nm}$ for P4. A computer equipped with Chromatographic Station software (Wufeng Scientific Instruments Co. Ltd.) for HPLC systems was used to acquire and process chromatographic data. Peak area was used as the analytical measurement. A column heater (model 500; Wufeng Scientific Instruments Co. Ltd., Shanghai, China), maintained at $15^{\circ} \mathrm{C}$, was used to obtain cloud point concentration. Centrifugation with calibrated centrifugal tubes (Beijing Medicinal Instrument Co., Beijing, PR China) was used to accelerate the phase- separation process. Easypure deionized water (Distilled Water Center, China Agricultural University, Beijing, China) was used in this study. An Agilent syringe was used for injecting the sample $(15 \mu \mathrm{L})$ into the loop to determine the concentrations of $\mathrm{P} 4$, testosterone, and $\mathrm{ADD}$ in the extracted rumen fluids.

\section{Feed Analysis}

Samples of the forages and concentrate were analyzed following AOAC International (1999) for DM (method 930.5), CP (method 984.13), calcium (method 927.02), phosphorus (method 984.27), and ash (method 942.05). Both NDF and ADF were analyzed (Van Soest et al., 1991) and corrected for residual ash content. The NFC content was calculated as follows: $\mathrm{NFC}=100-(\mathrm{NDF}$ $+\mathrm{CP}+$ ether extract + ash). The $\mathrm{NE}_{\mathrm{L}}$ was calculated according to NRC (2001).

\section{Calculations}

In experiment 2 , the $\mathrm{P} 4$ concentration $(\mathrm{ng} / \mathrm{mL})$ at different incubation times $\left(C_{t}\right)$ was fitted to a 1-compartment model (Dhillon and Gill, 2006) as Equation 1:

$$
C_{t}=C_{p 0} \times e^{-k_{e} \times t},
$$

where $t$ is the time after dosing $\mathrm{P} 4(t=0$ at the time the dose was administered), $C_{p 0}$ is the initial $\mathrm{P} 4$ concentration at time $t=0$ when the dose was administered, and $k_{e}$ is the $\mathrm{P} 4$ elimination rate constant.

Calculation of the time until half of the initial $\mathrm{P} 4$ inclusion was eliminated [i.e., half time $\left(\mathrm{T}_{1 / 2}\right)$ ] is shown in Equation 2:

$$
\mathrm{T}_{1 / 2}=\log \left(2 / k_{e}\right),
$$

where $k_{e}$ is the same as described for Equation 1.

Microbial transformation of $\mathrm{P} 4$ into testosterone (MTPT) during the in vitro incubation was calculated as in Equation 3:

$$
\operatorname{MTPT}=\frac{\left(C_{t}-C_{t r}\right)}{\left(C_{p 0}-C_{p r}\right)},
$$

where $C_{p 0}$ is the same as in Equation $1, \mathrm{C}_{p r}$ is the residual concentration $(\mathrm{ng} / \mathrm{mL})$ of $\mathrm{P} 4$ in culture fluids after the incubation, $C_{t}$ is the testosterone concentration (ng/ $\mathrm{mL}$ ) in culture fluids from $\mathrm{P} 4$ dose treatment after the incubation, and $C_{t r}$ is the testosterone concentration $(\mathrm{ng} / \mathrm{mL})$ in culture fluids from zero $\mathrm{P} 4$ dose treatment after the incubation. 
Microbial transformation of P4 into ADD (MTPD) during the in vitro incubation was calculated as in Equation 4:

$$
M T P D=\frac{\left(C_{d}-C_{d r}\right)}{\left(C_{p 0}-C_{p r}\right)},
$$

where $C_{p 0}$ and $C_{p r}$ is the same as in Equation $1, C_{d}$ is ADD concentration $(\mathrm{ng} / \mathrm{mL})$ in culture fluids from $\mathrm{P} 4$ dose treatment after the incubation, and $C_{d r}$ is $\mathrm{ADD}$ concentration $(\mathrm{ng} / \mathrm{mL})$ in culture fluids from zero P4 dose treatment after the incubation.

\section{Statistical Analysis}

Data in experiment 1 were analyzed by using PROC MIXED of SAS Institute (2004) according to the following model as Equation 5:

$$
Y_{i j k l}=\mu+S_{i}+P_{j}+C k_{(i)}+T_{l}+S T_{i l}+\varepsilon_{i j k l}
$$

where $Y_{i j k l}$ is the response variable, $\mu$ is the overall mean, $S_{i}$ is the effect of square $i(i=1$ to 5$), P_{j}$ is the effect of period $j(j=1$ to 5$), C k_{(i)}$ is the random effect of cow $k(k=1$ to 5 ; within square $i), T_{l}$ is the fixed effect of treatment ( $l=$ TMR1 to 5$), S T_{i l}$ is the interaction between square $i$ and treatment $l$, and $\varepsilon_{i j k l}$ is the residual error. Sampling time and treatment were added to the model for the analysis of P4, testosterone, and ADD concentrations, and were analyzed as repeated measures by using PROC MIXED. Firstorder autoregressive and compound symmetry (homogeneous and heterogeneous) were tested as covariance structures, and the covariance structure with the least Akaike information criterion was retained in the final model. Sums of squares for treatment were separated into single-degree-of-freedom preplanned orthogonal contrasts. Results are reported as least squares means and standard errors of the means between treatments or between sampling times.

Data in experiment 2 was analyzed using PROC GLM of SAS Institute (2004). Data were analyzed according to the following model:

$$
Y_{i j k}=\mu+D_{i}+P_{j}+C_{k}+e_{i j k}
$$

where $Y_{i j k}$ is the dependent variable, $\mu$ is the overall mean, $D_{i}$ is the fixed effect of $\mathrm{P} 4$ treatment $(i=1$ to $6), P_{j}$ is the fixed effect of period $(j=0,6,12,24,36$, 48 , and $72 \mathrm{~h}$, respectively), $C_{k}$ is the random effect of repetitions ( $k=1$ to 5$)$, and $e_{i j k}$ is the residual error. The significance of difference among means were tested using Duncan's multiple range test, and the repetition effects were further divided into linear and quadratic effects using orthogonal polynomial contrasts.

\section{RESULTS}

\section{Diurnal Variations of P4, Testosterone, and ADD Levels in Rumen Fluids}

As shown in Table 2, the TMR with different forage combinations did not affect ruminal concentrations of $\mathrm{P} 4$, testosterone, and ADD $(P=0.24)$. The highest pooled mean of ruminal $\mathrm{P} 4$ concentration occurred in TMR5, and the lowest occurred in TMR1 across different diurnal sampling times $(P<0.001)$, whereas no differences were observed among TMR2 and TMR3. The pooled means of ruminal concentrations of testosterone and ADD in TMR4 and TMR5 were greater than those means in TMR1 and TMR2 across different diurnal sampling times $(P<0.001)$.

In Figure 2, pooled means of ruminal progesterone (Figure 2a), testosterone (Figure 2b), and ADD (Figure 2c) at different diurnal sampling times were presented, regardless of TMR, with different forage combinations fed to the cows. The rumen $\mathrm{P} 4$ concentration was higher at nighttime (from 2100 to $0500 \mathrm{~h}$ ) than daytime (from 0900 to $1700 \mathrm{~h}$ ), and varied from 5.21 to $6.61 \mathrm{ng} /$ $\mathrm{mL}$ over the 24 -h period. Additionally, the ruminal P4 concentration decreased in 2 periods, which occurred after 0100 and $1300 \mathrm{~h}$. The lowest $\mathrm{P} 4$ concentrations occurred in the morning $(0700 \mathrm{~h})$ and afternoon feeding $(1900 \mathrm{~h})$, respectively. Thereafter, P4 concentration in the rumen continuously increased until the next decreased cycle. In accordance with the pattern of diurnal variation of ruminal $\mathrm{P} 4$ concentration, the diurnal variations in both testosterone and ADD were higher at night and lowest at 1900 and $0700 \mathrm{~h}(P<$ 0.001), respectively. Compared with $\mathrm{P} 4$ concentration, the ruminal testosterone and ADD concentrations were lower, and varied from 1.37 to $1.61 \mathrm{ng} / \mathrm{mL}$ and from 4.10 to $5.51 \mathrm{ng} / \mathrm{mL}$, respectively.

\section{Microbial P4 Transformation into Testosterone and ADD by Mixed Rumen Microorganisms}

Microbe-free controls (not listed) established that microbes, and not other elements, in the rumen fluids were responsible for conversion of the steroids. As shown in Table 3, the methanol vehicle also did not affect the metabolism of the endogenous steroids. The increased $\mathrm{P} 4$ concentration in culture fluids increased the residual $\mathrm{P} 4$ concentration and yield of testosterone and ADD in culture fluids at different incubation times $(P<0.001)$, and the concentrations of $\mathrm{P} 4$, testosterone, and ADD in culture fluids declined with the increase in incubation time. 
Table 2. Ruminal progesterone, testosterone, and androsta-1,4-diene-3,17-dione (ADD) concentrations at different sampling times of lactating dairy cows fed 5 TMR differing in forage combination (experiment 1)

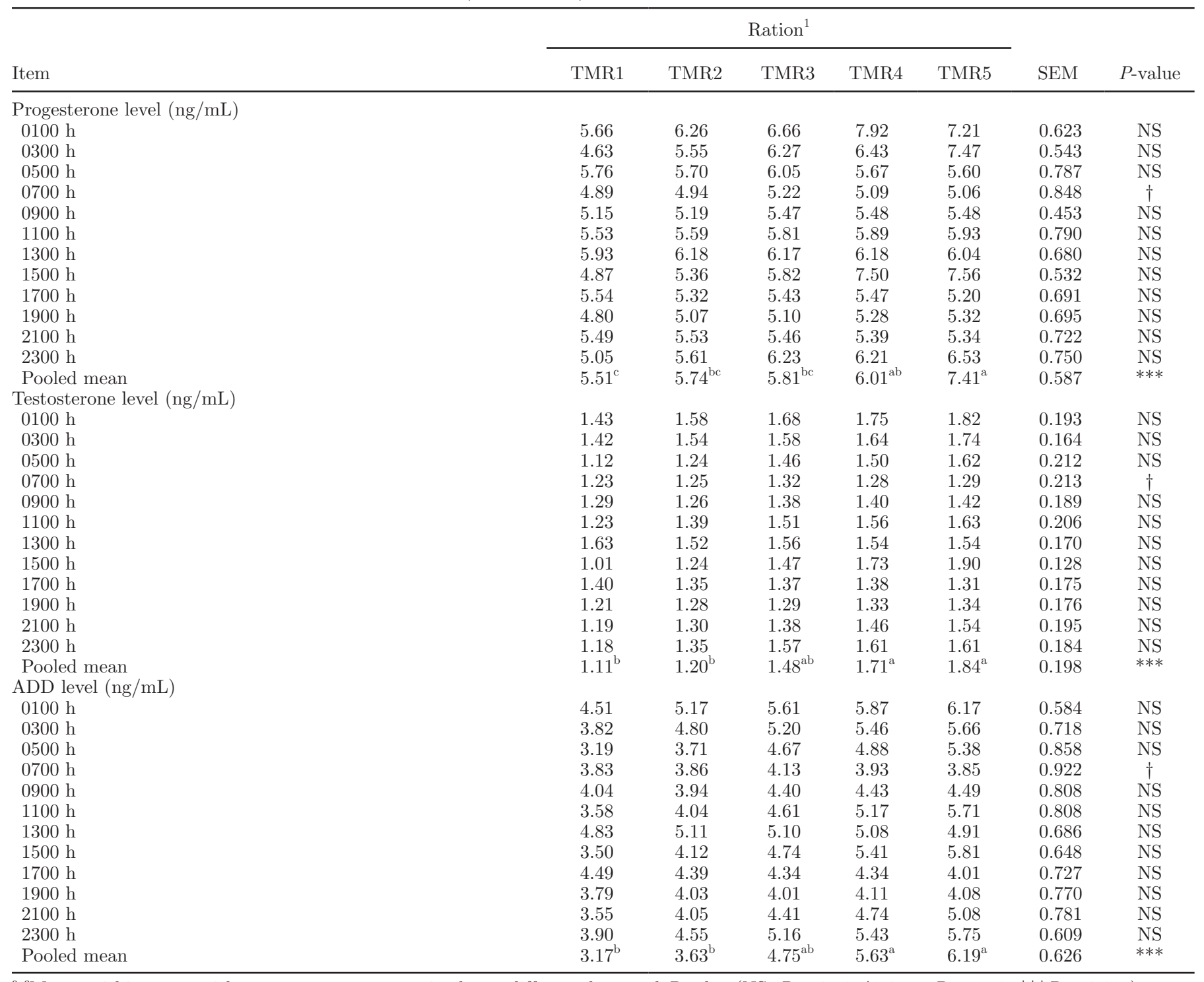

${ }^{\mathrm{a}-\mathrm{c}}$ Means within a row without a common superscript letter differ at the noted $P$-value (NS: $P>0.10 ; \dagger 0.05<P<0.10$; $* * * P<0.001$ ).

${ }^{1}$ Total mixed rations with the following forage combinations: TMR $1=$ corn stover; TMR $2=$ corn stover plus ensiled corn stover; TMR3 $=$ ensiled corn stover plus Chinese wild ryegrass hay; TMR $4=$ Chinese wild ryegrass hay plus corn silage; TMR $5=$ corn silage plus Chinese wild ryegrass plus alfalfa hay.

The elimination of $\mathrm{P} 4$ in the culture fluids against different incubation times was well fitted to the 1-compartment model $\left(\mathrm{R}^{2}>0.94\right.$; Table 4$)$. The elimination rate $\left(k_{e}\right)$ peaked at the $\mathrm{P} 4$ addition of $20 \mathrm{ng} / \mathrm{mL}$ and declined with the further increased $\mathrm{P} 4$ addition. The $\mathrm{P} 4$ addition groups exhibited shorter time $\left(\mathrm{T}_{1 / 2}\right)$ than the control group when half of the initial $\mathrm{P} 4$ inclusion $\left(C_{p 0}\right)$ was eliminated, and the lowest $\mathrm{T}_{1 / 2}$ value occurred at the $\mathrm{P} 4$ dose of $20 \mathrm{ng} / \mathrm{mL}$.
During all incubation times, MTPT (Table 4) differed among the different $\mathrm{P} 4$ addition groups $(P<$ 0.01). Meanwhile, MTPD at all incubation times in $\mathrm{P} 4$ addition groups declined with the increase in $\mathrm{P} 4$ addition. Regardless of $\mathrm{P} 4$ addition level, the pooled means of MTPT and MTPD (Figure 3) decreased with increased incubation time $(P<0.001)$, and the highest values of MTPT and MTPD occurred at $6 \mathrm{~h}$. 


\section{DISCUSSION}

\section{Ruminal P4, Testosterone, and ADD Variation Affected by Rations Fed to Dairy Cows}

Rhind (1992) reported that nutritional factors (e.g., energy and protein) directly influenced the hypothalamus-pituitary function through changes in the sensitivity of target organs to estradiol, progesterone, and other hormonal feedback and, therefore, gonadotropin profiles. In the present study, the same concentrate was applied in $5 \mathrm{TMR}$, but the $\mathrm{CP}$ content of 5 forages in different forage combinations of the TMR was ranked as alfalfa hay $(225 \mathrm{~g} / \mathrm{kg}$ of $\mathrm{DM})>$ whole corn silage $(102.1 \mathrm{~g} / \mathrm{kg}$ of DM) $>$ ensiled corn stover $(84.4 \mathrm{~g} / \mathrm{kg}$ of $\mathrm{DM})>$ Chinese wild ryegrass hay $(72.7 \mathrm{~g} / \mathrm{kg}$ of DM) $>$ corn stover $(65 \mathrm{~g} / \mathrm{kg}$ of DM). Consequently, both energy and protein levels are higher in the TMR with the forage combination of corn silage plus alfalfa hay or Chinese wild ryegrass hay, or both, than the TMR with the corn stover-based forage combination (Table 1). Beal et al. (1978) noted that serum P4 concentration was decreased $23.63 \%$ when cows were fed a low-energy diet (net energy level of $3.9 \mathrm{Mcal} / \mathrm{d}$ ), which might explain why low concentration of $\mathrm{P} 4$ entered the rumen of the cow fed the TMR with the corn stover-based forage combination. Additionally, both corn stover and ensiled corn stover were also characterized by high NDF and ADF contents with poor palatability compared with Chinese wild ryegrass, alfalfa hay, and corn silage. Shelford (1996) demonstrated that effective degradability of DM and protein in the rumen was ranked as alfalfa hay $>$ corn silage $>$ pasture grass hay. Therefore, DMI in the present study was ranked as TMR $5(15.57 \mathrm{~kg} / \mathrm{d})$ $>$ TMR4 $(15.56 \mathrm{~kg} / \mathrm{d})>$ TMR3 $(15.49 \mathrm{~kg} / \mathrm{d})>$ TMR2 $(15.27 \mathrm{~kg} / \mathrm{d})>$ TMR1 $(15.11 \mathrm{~kg} / \mathrm{d})$ (H.-J. Yang, unpublished data). In a recent study, Blache et al. (2008) noted that a dietary increase in energy and protein intake induced the increases in gonadotropin-releasing hormone, luteinizing hormone pulse frequencies, and follicle-stimulating hormone secretion, which could explain why high ruminal $\mathrm{P} 4$ concentration in the present study was observed in the high-energy and high-protein TMR with the forage combination of corn silage plus alfalfa hay or Chinese wild ryegrass hay, or both.

Richards and Hendrickson (1964) reported that hepatic cells and tissues metabolized $\mathrm{P} 4$ to testosterone and thereafter the testosterone was partially oxidized to ADD. The metabolites of testosterone and ADD entered the rumen with saliva or via the rumen epithelium (Borisenkov et al., 2003; Borisenkov et al., 2006; Han et al. 2006), which could explain why ruminal concentrations of testosterone $\left(\mathrm{Y}=0.246 \times \mathrm{X}+0.037 ; \mathrm{R}^{2}=\right.$ $0.95 ; P<0.001)$ and ADD $\left(\mathrm{Y}=0.823 \times \mathrm{X}+0.106 ; \mathrm{R}^{2}\right.$
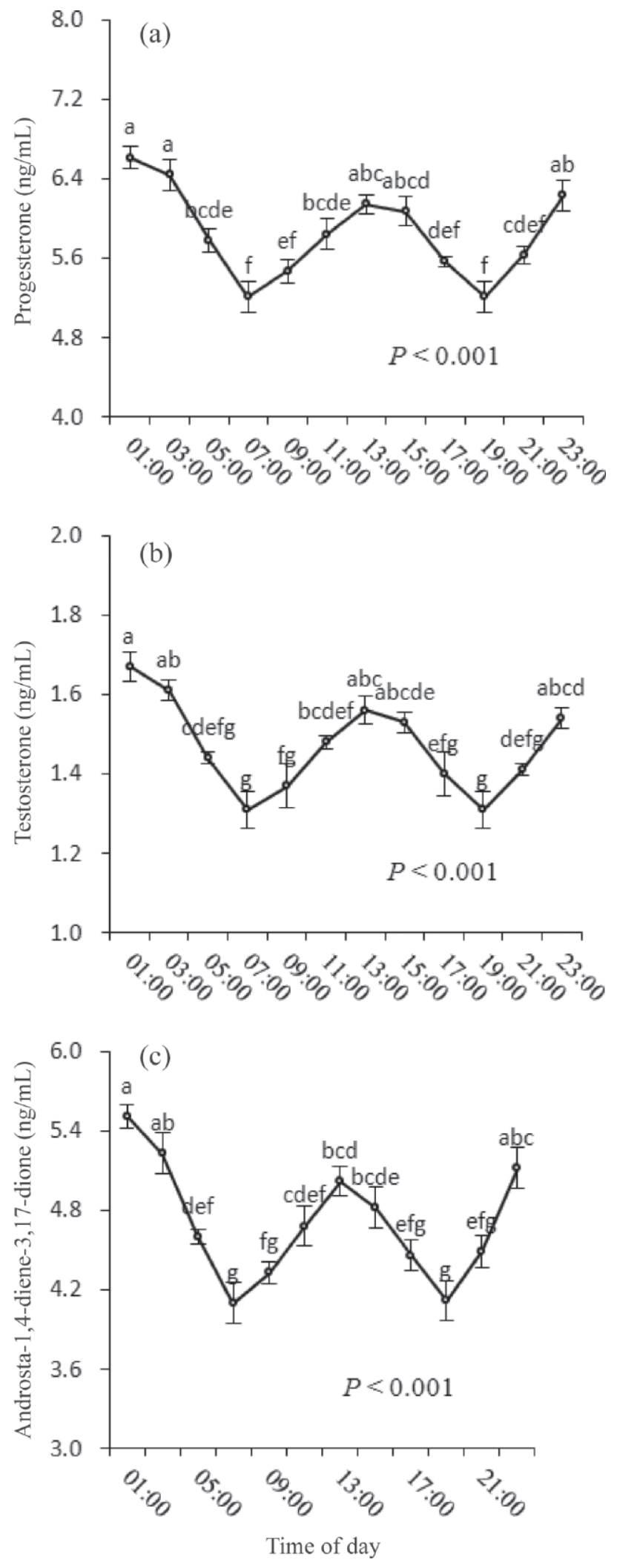

Figure 2. Diurnal variation in ruminal progesterone (a), testosterone (b), and androsta-1,4-diene-3,17-dione (c), on average, of lactating dairy cows fed 5 TMR differing in forage combination (experiment 1 ). 
Table 3. Effect of progesterone (P4) addition at different levels on P4 residue, testosterone and androsta-1,4-diene-3,17-dione (ADD) concentrations in cultural fluids of a maize-rich feed mixture (maize meal:Chinese ryegrass hay $=4: 1$ ) incubated together with rumen fluids of lactating dairy cows at different incubation times (experiment 2)

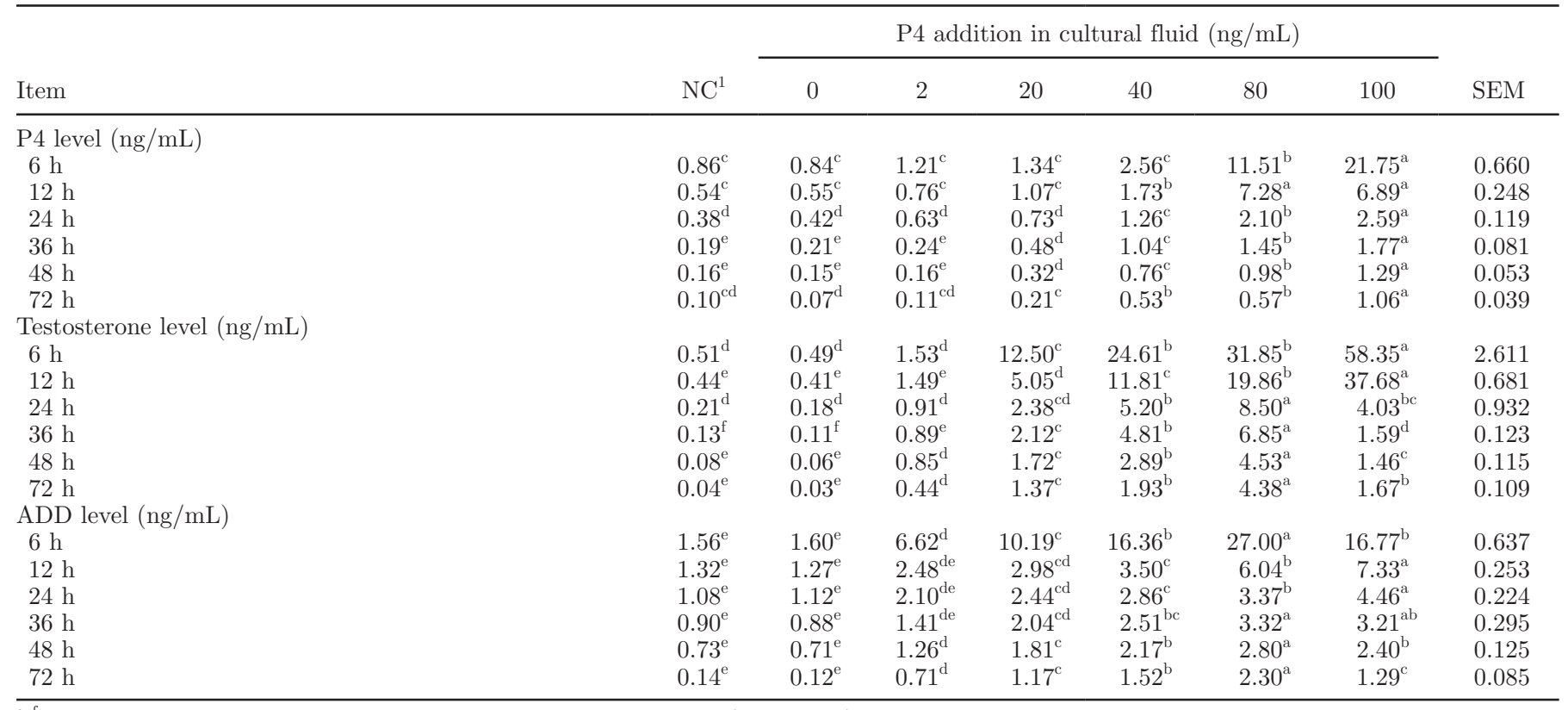

${ }^{\mathrm{a}-\mathrm{f}}$ Means within a row without a common superscript letter differ $(P<0.001)$.

${ }^{1}$ Negative control with no P4 and no methanol inclusion.

Table 4. Microbial transformation of progesterone (P4) into testosterone and androsta-1,4-diene-3,17-dione (ADD) in cultural fluids of a maizerich feed mixture (maize meal:Chinese ryegrass hay $=4: 1$ ) incubated together with rumen fluids of lactating dairy cows at different incubation times (experiment 2$)^{1}$

\begin{tabular}{|c|c|c|c|c|c|c|c|c|}
\hline Item $^{2}$ & \multicolumn{6}{|c|}{$\mathrm{P} 4$ addition in cultural fluid $(\mathrm{ng} / \mathrm{mL})$} & SEM & $P$-value \\
\hline \multicolumn{9}{|c|}{ P4 elimination kinetics } \\
\hline$k_{e}(/ \mathrm{h})$ & $0.09(0.01)$ & $0.17(0.04)$ & $0.47(0.08)$ & $0.45(0.06)$ & $0.30(0.03)$ & $0.25(0.01)$ & - & - \\
\hline $\mathrm{R}^{2}$ & 0.94 & 0.96 & 0.97 & 0.97 & 0.98 & 0.98 & - & - \\
\hline $\mathrm{T}_{1 / 2}(\mathrm{~h})$ & 3.06 & 2.46 & 1.46 & 1.49 & 1.88 & 2.08 & - & - \\
\hline \multicolumn{9}{|l|}{ MTPT } \\
\hline $12 \mathrm{~h}$ & $0.29^{\mathrm{bc}}$ & $0.50^{\mathrm{a}}$ & $0.22^{\mathrm{c}}$ & $0.28^{\mathrm{bc}}$ & $0.26^{\mathrm{c}}$ & $0.39^{\mathrm{ab}}$ & 0.038 & $* * *$ \\
\hline $24 \mathrm{~h}$ & $0.12^{\mathrm{b}}$ & $0.31^{\mathrm{a}}$ & $0.10^{\mathrm{b}}$ & $0.12^{\mathrm{b}}$ & $0.10^{\mathrm{b}}$ & $0.02^{\mathrm{b}}$ & 0.035 & $* * *$ \\
\hline $36 \mathrm{~h}$ & $0.06^{\mathrm{c}}$ & $0.29^{\mathrm{a}}$ & $0.09^{\mathrm{bc}}$ & $0.11^{\mathrm{b}}$ & $0.08^{\mathrm{bc}}$ & $0.01^{\mathrm{d}}$ & 0.012 & $* * *$ \\
\hline $48 \mathrm{~h}$ & $0.03^{\mathrm{cd}}$ & $0.28^{\mathrm{a}}$ & $0.07^{\mathrm{b}}$ & $0.06^{\mathrm{b}}$ & $0.05^{\mathrm{bc}}$ & $0.01^{\mathrm{d}}$ & 0.007 & $* * *$ \\
\hline $72 \mathrm{~h}$ & $0.01^{\mathrm{c}}$ & $0.14^{\mathrm{a}}$ & $0.06^{\mathrm{b}}$ & $0.04^{\mathrm{b}}$ & $0.05^{\mathrm{b}}$ & $0.01^{\mathrm{c}}$ & 0.005 & $* * *$ \\
\hline \multicolumn{9}{|l|}{ MTPD } \\
\hline $6 \mathrm{~h}$ & $0.81^{\mathrm{a}}$ & $0.75^{\mathrm{a}}$ & $0.41^{\mathrm{b}}$ & $0.37^{\mathrm{b}}$ & $0.36^{\mathrm{b}}$ & $0.20^{\mathrm{c}}$ & 0.049 & $* * *$ \\
\hline
\end{tabular}

${ }^{\mathrm{a}-\mathrm{f}}$ Means within a row without a common superscript letter differ at the noted $P$-value $(* * P<0.01 ; * * * P<0.001)$.

${ }^{1}$ Values in parentheses are SE.

${ }^{2}$ Progesterone concentration $\left(C_{t} ; \mathrm{ng} / \mathrm{mL}\right)$ at different incubation times was fitted to a 1-compartment model (Dhillon and Gill, 2006) as follows: $C_{t}=C_{p 0} \times e^{-k_{e} \times t}$, where $t$ is the time after the $\mathrm{P} 4$ was added $\left(t=0\right.$ at the time the dose was administered), $C_{p 0}$ is the initial P4 concentration at time $t=0$ when the dose was administered, and $k_{e}$ is the $\mathrm{P} 4$ elimination rate constant; $\mathrm{T}_{1 / 2}=$ time until half of the initial $\mathrm{P} 4$ inclusion was eliminated; MTPT $=$ microbial transformation of P4 into testosterone; MTPD = microbial transformation of P4 into ADD. 

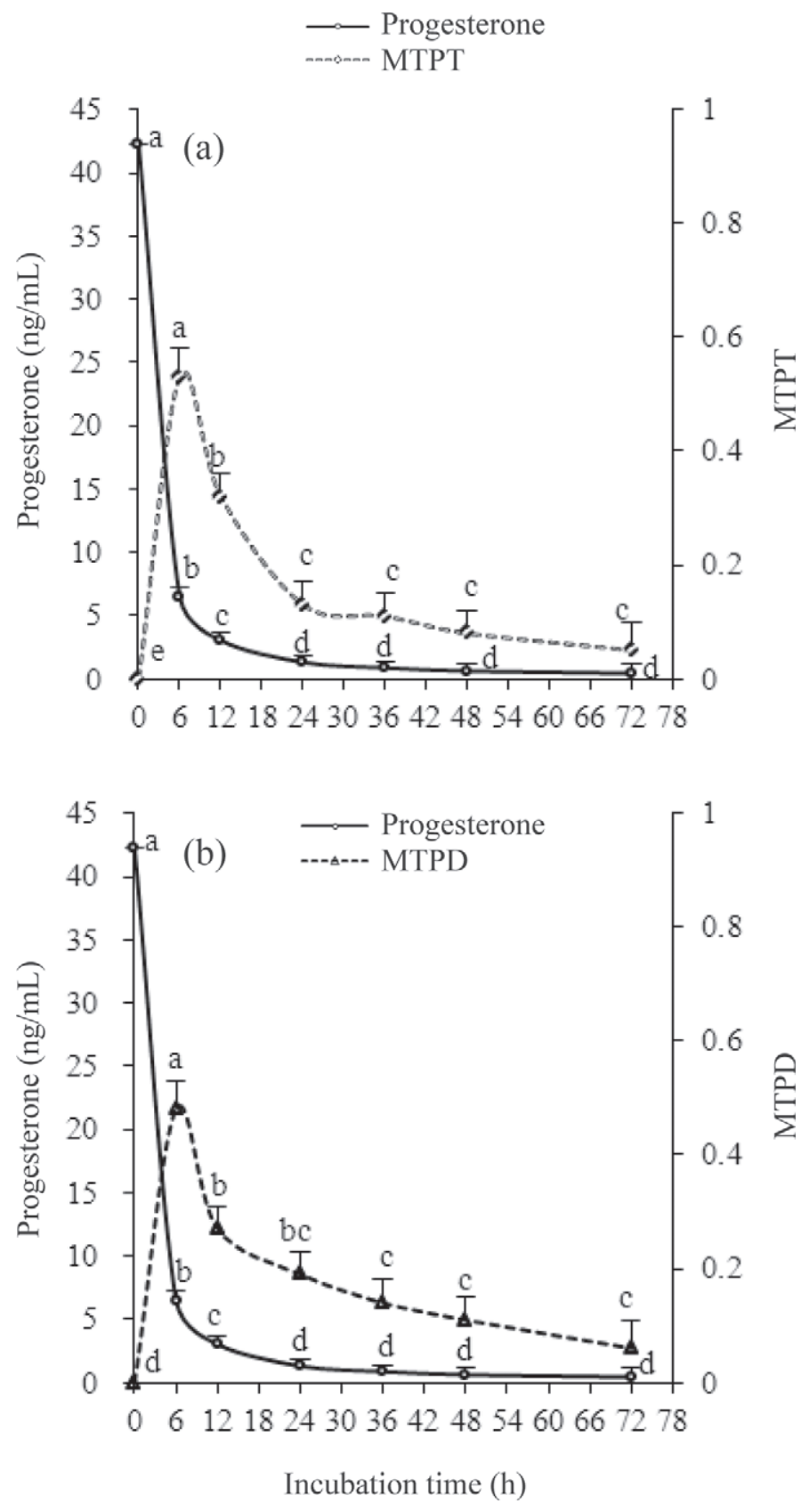

Figure 3. Microbial transformation of progesterone into testosterone (MTPT; a) and androsta-1,4-diene-3,17-dione (MTPD; b) in cultural fluids, on average, of a maize-rich feed mixture (maize meal:Chinese ryegrass hay $=4: 1$ ) in vitro incubated together with ruminal fluids obtained from lactating dairy cows (experiment 2). Values without a common letter $(\mathrm{a}-\mathrm{d})$ differ among different incubation times $(P<0.001)$.

$=0.95 ; P<0.001)$ in the present study were positively correlated with the ruminal $\mathrm{P} 4$ concentration in the cows fed 5 TMR with different forage combinations.

Vasconcelos et al. (2003) noted that sudden feeding in comparison with nonfeeding decreased ruminal concentrations of $\mathrm{P} 4$, testosterone, and $\mathrm{ADD}$ concentration in lactating Holstein cows, and Sangsritavong et al. (2002) explained that this could be due to the sudden feeding increasing blood flow and clearance of P4 by hepatic cells.

\section{Microbial Transformation of P4 into Testosterone and ADD in the Rumen}

Freetly and Ferrell (1994a,b) demonstrated that the liver had comparatively low contributions to the metabolite production of testosterone and ADD in ruminant animals, and this was further confirmed by Lundh (1995) in his study of metabolite of isoflavonic phytoestrogens (e.g., daidzein and genistein) in the liver of domestic cattle and sheep. In experiment 2 of the present study, when the $\mathrm{P} 4$ was incubated with microbe-free rumen fluid, the concentrations of $\mathrm{P} 4$, testosterone, and ADD did not differ with different incubation times. In contrast, the concentrations of $\mathrm{P} 4$, testosterone, and $\mathrm{ADD}$ varied when the mixed rumen microorganisms occurred, and these results suggest that the metabolic variation of testosterone and ADD in response to different addition levels of $\mathrm{P} 4$ in culture fluids is caused by microbial $\mathrm{P} 4$ transformation in mixed rumen microorganisms, regardless of those $\mathrm{P} 4$ metabolites entering the rumen via saliva or the rumen epithelium.

García-Gómez et al. (2013) reported that some bacteria not from the rumen were capable of metabolizing P4 with their distinct enzymes, including hydroxysteroid dehydrogenase (HSD), an enzyme that regulates the balance between active and inactive $\mathrm{P} 4$. Occurrence of microbial $\mathrm{P} 4$ transformation could be related to the bacteriostatic action of P4. Lester et al. (1958) reported that $\mathrm{P} 4$ decreased membrane permeability and inhibited extracellular nutrient uptake in fungi. In a subsequent study, Yielding et al. (1960) noted that P4 was an inhibitor of reduced nicotinamide adenine dinucleotide oxidase, and it inhibited the flow of electrons in the cytochrome system while decreasing the available energy to the bacteria cell. Križančić Bombek et al. (2008) found that P4 jeopardized cell wall stability of yeast, and was further found to inhibit the growth of filamentous fungus Trichophyton mentagrophytes (Schär et al., 1986) and Rhizopus nigricans (Breskvar et al., 1995). Yotis and Stanke (1966) examined P4 in vitro for bacterial activity against gram-positive bacteria, and found inhibition of $\mathrm{P} 4$ seldomly against gramnegative bacteria. It is well known that the rumen is inhabited by gram-negative bacteria and gram-positive bacteria (Hungate, 1966), and P4 might be involved in inhibition of gram-positive bacteria in the rumen.

The rumen is inhabited by bacteria, protozoa, and fungi in which gram-positive bacteria play a dominant role in nutrient digestion and metabolism (Hungate, 1966). 
Križančić Bombek et al. (2008) reported that microbial transformation of $\mathrm{P} 4$ by inducible steroid-transforming enzymes increased the polarity extent of steroids and effectively contributed to their detoxification. When P4 enters the rumen with saliva or via the rumen epithelium, microbial $\mathrm{P} 4$ transformation might be essential for ruminal microorganisms, particularly gram-positive bacteria to reduce bacteriostatic action of $\mathrm{P} 4$. Morse and Fitzgerald (1974) noted that the bacteriostatic action of $\mathrm{P} 4$ depended on the $\mathrm{P} 4$ concentration, and the higher the level of $\mathrm{P} 4$, the more significant the bacteriostatic action that occurred, which could explain why $\mathrm{P} 4$ added to the culture fluids in experiment 2 of the present study was rapidly transformed to testosterone and ADD by ruminal microorganisms in the $\mathrm{P} 4$-addition groups compared with the zero-P4 control. The elimination rate $\left(k_{e}\right)$ of $\mathrm{P} 4$ in experiment 2 of the present study depended on not only the level of P4 but also the available $\mathrm{P} 4$ binding sites of the microbial cell membrane. Miller and Morse (1977) demonstrated that a $\mathrm{P} 4$ concentration of $2,000 \mathrm{ng} / \mathrm{mL}$ reached a $\mathrm{P} 4$ binding equilibrium for Neisseria gonorrhoeae CS-7. In contrast, rumen mixed microorganisms were sensitive to low concentrations of P4 in the current study, and the binding equilibrium might have occurred at the $\mathrm{P} 4$ addition level of $20 \mathrm{ng} / \mathrm{mL}$, although the available P4 binding sites was not determined in experiment 2. Miller and Morse (1977) reported that a P4 concentration over $10 \mu \mathrm{g} / \mathrm{mL}$ inhibited the growth of $N$. gonorrhoeae CS-7. Hall (1991) noted that microbial transformation of P4 into polar testosterone was catalyzed by a cytochrome P-450 monooxygenase in higher eukaryotes, but some fungi, such as Cylindrocarpon radicicola (Itagaki, 1986) and Paecilomyces lilacinus (Vitas et al., 1995), had the ability to utilize a cytosolic non-P-450 monooxygenase for microbial P4 transformation into testosterone. The results reported in the above studies demonstrate that fungi also play an important role in effective biotransformation of P4. Until now, no related reports are available for anaerobic fungi in the rumen.

Križančić Bombek et al. (2008) demonstrated that the most efficient biotransformation of $\mathrm{P} 4$ occurred in the early logarithmic phase of microbial growth of Hortaea werneckii isolated from hypersaline water, which could explain why half of the initial P4 included in the culture fluids in experiment 2 of the present study were rapidly eliminated around the incubation time range of 1.46 to $3.06 \mathrm{~h}$ under different $\mathrm{P} 4$ addition levels. The testosterone produced in the culture fluid declined with incubation time and was oxidized to ADD, and this might be driven by the bactericidal action of testosterone as well as P4 reported by Križančić Bombek et al. (2008).
There were 2 microbial pathways for transforming testosterone into ADD. One was an oxygenase-dependent pathway in which 3 -ketosteroid- $\Delta^{1}$-dehydrogenase played a key role (Choi et al., 1995), and another was an oxygenase-independent testosterone catabolic pathway in which $3 \alpha-\mathrm{HSD}$ was involved (Leu et al., 2011). The expression of $3 \alpha-\mathrm{HSD}$ was highly inducible in the presence of testosterone (Kisiela et al., 2012), which could explain why the rapid microbial transformation of testosterone into ADD occurred in experiment 2 of the present study.

The metabolite ADD is regarded as the most important steroidal derivative in the process of steroid bioconversion, which has been widely confirmed through microbial transformation from cholesterol and phytosterols and used for the production of sex hormones, anabolic steroids, and even adrenocortical hormones (Fernandes et al., 2003). The metabolite of ADD was utilized as a carbon source by microorganisms (Leu et al., 2011) or was transformed to other steroidal derivatives. The effective microbial transformation of $\mathrm{P} 4$ to ADD in the present study confirmed that ruminal microorganisms are important potential species to produce ADD. To date, no information about the microbial transformation of $\mathrm{P} 4$ by specific ruminal microorganisms is available.

The results obtained in the present study suggest that P4 entering the rumen can be altered by dietary forage type and quality and regulated by microbial transformation function of rumen microbiota. The effect of P4 on feed digestion and metabolism in the rumen may need to be further investigated in future research.

\section{CONCLUSIONS}

Ruminal P4, testosterone, and ADD concentrations of lactating dairy cows were greater in the TMR with the forage combination of corn silage plus alfalfa hay or Chinese wild ryegrass hay, or both, than the TMR with the corn stover-based forage combination. Diurnal variation pattern showed that $\mathrm{P} 4$, testosterone, and ADD concentrations in the rumen were greater at nighttime than daytime and reached a peak $6 \mathrm{~h}$ after feeding in the morning or afternoon. The results obtained in the batch culture demonstrated that the rumen microorganisms had great ability of microbial $\mathrm{P} 4$ transformation into testosterone and $\mathrm{ADD}$, depending on incubation time and initial $\mathrm{P} 4$ addition in culture fluids. In summary, P4 entering the rumen can be altered by dietary forage type and quality and regulated by the microbial transformation function of rumen microbiota, suggesting that steroid interregulation occurred between the host and its microorganisms in the rumen. 


\section{ACKNOWLEDGMENTS}

The authors appreciate the financial support of the National Key Basic Research Program (project no. 2011CB100801) and Modern Dairy Industrial Science and Technology Program (project no. 2012BAD12B02) of The Ministry of Science and Technology of the People's Republic of China (Beijing, China) and Innovation Funds for Graduate Students of China Agricultural University (Beijing, China).

\section{REFERENCES}

AOAC International. 1999. Official Methods of Analysis. 16th ed. AOAC Int., Arlington, VA.

Beal, W. E., R. E. Short, R. B. Staigmiller, R. A. Bellows, C. C. Kaltenbach, and T. G. Dunn. 1978. Influence of dietary energy intake on bovine pituitary and luteal function. J. Anim. Sci. 46:181-188.

Blache, D., S. K. Maloney, and D. K. Revell. 2008. Use and limitations of alternative feed resources to sustain and improve reproductive performance in sheep and goats. Anim. Feed Sci. Technol. 147:140-157.

Borisenkov, M. F., L. A. Bakutova, A. N. Murav'eva, V. A. Tallina, and A. M. Kaneva. 2006. Dynamics of rumenoenteral transport of progesterone in sheep in chronic experiment. Ross. Fiziol. Zh. Im. I M Sechenova 92:374-378. [Article in Russian.]

Borisenkov, M. F., M. A. Vă̌kishnorăte, and A. M. Kaneva. 2003. Progesterone transport across the wall of the rumen of sheep. Ross. Fiziol. Zh. Im. I M Sechenova 89:1161-1166. [Article in Russian.]

Breskvar, K., Z. Ferenčak, and T. Hudnik-Plevnik. 1995. The role of cytochrome $\mathrm{p} 45011 \alpha$ in detoxification of steroids in the filamentous fungus Rhizopus nigricans. J. Steroid Biochem. Mol. Biol. 52:271275.

Carlström, K. 1966. Metabolism of progesterone by Streptomyces griseus. Acta Chem. Scand. 20:2620-2622.

Choi, K.-P., I. Molnar, M. Yamashita, and Y. Murooka. 1995. Purification and characterization of the 3 -ketosteroid- $\Delta^{1}$-dehydrogenase of Arthrobacter simplex produced in Streptomyces lividans. J. Biochem. 117:1043-1049.

Cunningham, N. F., A. M. Symons, and N. Saba. 1975. Levels of progesterone, LH and FSH in the plasma of sheep during the oestrous cycle. J. Reprod. Fertil. 45:177-180.

Dhillon, S., and K. Gill. 2006. Basic Pharmacokinetics. Clinical Pharmacokinetics. Pharmaceutical Press, London, UK.

Fernandes, P., A. Cruz, B. Angelova, H. M. Pinheiro, and J. M. S. Cabral. 2003. Microbial conversion of steroid compounds: Recent developments. Enzyme Microb. Technol. 32:688-705.

Fonken, G. S., H. C. Murray, and L. M. Reineke. 1960. Pathway of progesterone oxidation by Cladosporium resinae. J. Am. Chem. Soc. 82:5507-5508.

Freetly, H. C., and C. L. Ferrell. 1994a. Kinetics of splanchnic progesterone metabolism in ewes fed two levels of nutrition. J. Anim. Sci. 72:2107-2112.

Freetly, H. C., and C. L. Ferrell. 1994b. Net uptakes of estradiol-17 beta and progesterone across the portal-drained viscera and the liver of ewes. J. Endocrinol. 141:353-358.

García-Gómez, E., B. González-Pedrajo, and I. Camacho-Arroyo. 2013. Role of sex steroid hormones in bacterial-host interactions. Biomed. Res. Int. 2013:928290.

Hall, P. F. 1991. Cytochrome P-450C ${ }_{21 S C C}$ : One enzyme with 2 actions: Hydroxylase and lyase. J. Steroid Biochem. Mol. Biol. 40:527-532.

Han, Z., G. Wang, W. Yao, and W. Zhu. 2006. Isoflavonic phytoestrogens-New prebiotics for farm animals: A review on research in China. Curr. Issues Intest. Microbiol. 7:53-60.

Hanukoglu, I. 1992. Steroidogenic enzymes: Structure, function, and role in regulation of steroid hormone biosynthesis. J. Steroid Biochem. 43:779-804.
Hungate, R. E. 1966. The Rumen and Its Microbes. Academic Press, New York, NY.

Itagaki, E. 1986. Studies on steroid monooxygenase from Cylindrocarpon radicicola ATCC 11011. Purification and characterization. J. Biochem. 99:815-824.

Kisiela, M., A. Skarka, B. Ebert, and E. Maser. 2012. Hydroxysteroid dehydrogenases (HSDs) in bacteria-A bioinformatic perspective. J. Steroid Biochem. Mol. Biol. 129:31-46.

Križančić Bombek, L., A. Lapornik, M. Ukmar, M. Matis, B. Črešnar, J. P. Katalinić, and M. Žakelj-Mavrič. 2008. Aspects of the progesterone response in Hortaea werneckii: Steroid detoxification, protein induction and remodelling of the cell wall. Steroids 73:14651474 .

Lester, G., D. Stone, and O. Hechter. 1958. The effects of deoxycorticosterone and other steroids on Neurospora crassa. Arch. Biochem. Biophys. 75:196-214.

Leu, Y.-L., P.-H. Wang, M.-S. Shiao, W. Ismail, and Y.-R. Chiang. 2011. A novel testosterone catabolic pathway in bacteria. J. Bacteriol. 193:4447-4455.

Lundh, T. 1995. Metabolism of estrogenic isoflavones in domestic animals. Proc. Soc. Exp. Biol. Med. 208:33-39.

Mani, S. 2003. Signalling mechanisms in progesterone-neurotransmitter interactions. J. Mol. Endocrinol. 30:127-137.

Menke, K. H., and H. Steingass. 1988. Estimation of the energetic feed value obtained from chemical analysis and gas production using rumen fluid. Anim. Res. Dev. 28:7-55.

Miller, R. D., and S. A. Morse. 1977. Binding of progesterone to Neisseria gonorrhoeae and other gram-negative bacteria. Infect. Immun. 16:115-123.

Morse, S. A., and T. J. Fitzgerald. 1974. Effect of progesterone on Neisseria gonorrhoeae. Infect. Immun. 10:1370-1377.

NRC. 2001. Nutrition Requirements of Dairy Cattle. National Academy Press, Washington, DC.

Rhind, S. M. 1992. Nutrition: Its effects on reproductive performance and its hormonal control in female sheep and goats. Pages 25-51 in Progress in Sheep and Goat Research. CAB International, Wallingford, UK.

Richards, J. H., and J. B. Hendrickson. 1964. The Biosynthesis of Steroids, Terpenes, and Acetogenins (Frontiers in Chemistry). W. A. Benjamin Inc., New York, NY.

Rothchild, I. 1981. The regulation of the mammalian corpus luteum. Recent Prog. Horm. Res. 37:183-298.

Sangsritavong, S., D. K. Combs, R. Sartori, L. E. Armentano, and M. C. Wiltbank. 2002. High feed intake increases liver blood flow and metabolism of progesterone and estradiol-17 $\beta$ in dairy cattle. J. Dairy Sci. 85:2831-2842.

SAS Institute. 2004. SAS/STAT User's Guide: Statistics, Version 9.1. SAS Institute Inc., Cary, NC.

Schär, G., E. P. Stover, K. V. Clemons, D. Feldman, and D. A. Stevens. 1986. Progesterone binding and inhibition of growth in Trichophyton mentagrophytes. Infect. Immun. 52:763-767.

Shelford, J. A. 1996. Degradability characteristics of dry matter and crude protein of forages in ruminants. Anim. Feed Sci. Technol. 57:291-311.

Stabenfeldt, G. H., L. L. Ewing, and L. E. McDonald. 1969. Peripheral plasma progesterone levels during the bovine oestrus cycle. J. Reprod. Fertil. 19:433-442.

Van Soest, P. J., J. B. Robertson, and B. A. Lewis. 1991. Methods for dietary fiber, neutral detergent fiber, and nonstarch polysaccharides in relation to animal nutrition. J. Dairy Sci. 74:3583-3597.

Vasconcelos, J. L. M., S. Sangsritavong, S. J. Tsai, and M. C. Wiltbank. 2003. Acute reduction in serum progesterone concentrations after intake in dairy cows. Theriogenology 60:795-807.

Vitas, M., D. Rozman, R. Komel, and S. L. Kelly. 1995. Progesterone side-chain cleavage by Paecilomyces lilacinus. Phytochemistry 40:73-76.

Wadhwa, L., and K. E. Smith. 2000. Progesterone side-chain cleavage by Bacillus sphaericus. FEMS Microbiol. Lett. 192:179-183.

Wang, L., Y.-Q. Cai, B. He, C.-G. Yuan, D.-Z. Shen, J. Shao, and G.B. Jiang. 2006. Determination of estrogens in water by HPLC-UV using cloud point extraction. Talanta 70:47-51. 
Wiltbank, M. C., A. H. Souza, J. O. Giordano, A. B. Nascimento, J. M. Vasconcelos, M. H. C. Pereira, P. M. Fricke, R. S. Surjus, F. C. S. Zinsly, P. D. Carvalho, R. W. Bender, and R. Sartori. 2012. Positive and negative effects of progesterone during timed AI protocols in lactating dairy cattle. Anim. Reprod. 9:231-241.

Yielding, K. L., G. M. Tompkins, J. S. Munday, and I. J. Cowley. 1960. The effects of steroids on electron transport. J. Biol. Chem. 235:3413-3416.
Yotis, W., and R. Stanke. 1966. Bacteriostatic action of progesterone on staphylococci and other microorganisms. J. Bacteriol. 92:1285-1289. 